\title{
SOME PROBLEMS OF THE EUROPEAN INFORMATION EXCHANGE MODEL IN THE FIELD OF THE LAW ENFORCEMENT COOPERATION
}

\author{
Simo MIHOV \\ "Neofit Rilski" South-West University, Blagoevgrad, Bulgaria \\ simo_mihov@abv.bg
}

\begin{abstract}
There are some mechanisms which ensure information exchange among the member states of the EU in the field of the law enforcement cooperation such as European Information Exchange Model (EIXM) and channels used the information with operational importance to be transferred from one authorized user to another such as the Secure Information Exchange Network Application (SIENA) and the system I-24/7. The article is devoted to defining of some problems of organizational and managerial character for improving the compatibility between these mechanisms and suggesting of some simple solutions the obstacles to be overcome.
\end{abstract}

Keywords: law enforcement cooperation, information exchange, EIXM

\section{Introduction}

The globalization of the contemporary world and society is a multi-aspect process, which brings together different positive and negative trends. There are some indisputable positive outcomes, which are consequences of the globalization in an EU dimension. However, there are also several negative aspects, which create risks and threats for the new European community. A trend with a direct connection to the common European globalization is the serious increase of the level of the cross-border crime, or more specifically the serious increase of the "crimes with an international element". The scope of the aforementioned category is composed by:

Crimes committed by foreigners on the territory of a certain national country; Crimes, whose act of perpetration starts on the territory of one country and continues on the territory of another country where the perpetration of the crime is finalized; Crimes affecting in some aspect two or more national countries.
The defined above kind of crime is contemporary characterized by increasingly growing parameters and high temps of development. Consequently, the competent law enforcement authorities face a challenge, which requires an adequate response. In order the crimes with an international element to be more efficiently and effectively combated, the EU establishes and fits special tools, which to be used by the competent authorities in the fight against the transnational crime, known in the theory and practice as "compensatory security measures".

\section{Compensatory Security Measures}

The compensatory security measures are mainly characterized by their "exterritoriality" - the delegate competence of national law enforcement authorities from one contracting country to act in an official capacity on the territory of another contracting country. The aforementioned tools (or instruments) for cross-border law enforcement cooperation considered as compensatory security measures are variety 
- Schengen Information System, Joint Investigation Teams, Mixed Patrols, Common Centers for Law Enforcement Cooperation, Cross-border "Hot" Pursuit, International Controlled Delivery, Crossborder Surveillance etc.

The most popular, mainly and daily used tool for cross-border law enforcement cooperation is the exchange of information among the competent law enforcement authorities from different member-countries of the EU. The information and more specifically the opportunity of access to information with operational importance was and still stays the most powerful weapon in the hands of the law enforcement authorities in order to be able effectively and efficiently to counter the crime at national, regional and international level. In practical perspective, the competent law enforcement authorities often face a situation where certain information with operational importance for one authority is in possession of other, or certain information with operational importance for one official authority could be easily obtained by other official authority and subsequently provided to the first official authority. The aforementioned is done in the frame of the so-called "information exchange". The problem related to the access and exchange of information with operational importance in the frame of cooperation between the law enforcement bodies exists at a national level and at international level as well without the cooperation between the EU member-states to be an exception of this rule.

\section{European Information Exchange Model (EIXM)}

The above is considered as a precondition with regard to the need of finding new active solutions for the optimization of the information exchange in the frame of European operational cooperation in the field of law enforcement. An effort in that direction is the European Information Exchange Model (EIXM). In 2012, the
Commission adopted a Communication to the Council and the European Parliament on the European Information Exchange Model (EIXM). EIXM recommends steps on how to increase the efficiency and improve the application of existing cooperation instruments.

It is considered, the legal frame of the EIXM is composed mainly of two international acts of legislation - the Prüm Council Decision (2008/615/JHA) and the decision 2006/960/JHA, known as "Swedish Initiative". [1]

\section{The Prüm Decision}

The origin of the Prüm Decision is a multilateral treaty signed in the German town of Prüm in 2005 by Germany, Spain, France, Luxembourg, the Netherlands, Austria, and Belgium. Given the considerable interest from the other EU States, the Commission supported the German initiative to transform this Treaty into an instrument binding all EU Member States. Consequently, the Council adopted the Prüm Decision and its implementing provisions.

The Prüm Decision contains rules for operational police cooperation such as joint patrols and introduced procedures for fast and efficient data exchange in specific areas. The core of the Prüm framework lays down provisions under which EU Member States grant each other access to their automated DNA analysis files, automated fingerprint identification systems, and vehicle registration data. DNA and fingerprint exchanges take place based on a "hit/no-hit" approach, which means that DNA profiles or fingerprints found at a crime scene in one EU Member State can be compared automatically with profiles held in the databases of other EU States. Car registration data (including licence plates and chassis numbers) are exchanged through national platforms that are linked to the online application "EUCARIS".

The Swedish Initiative provides a common legal framework for the effective and expeditious exchange of existing 
information and criminal intelligence between EU Member States' law enforcement authorities. This instrument, proposed by Sweden, was adopted in 2006 . It sets out rules for the cross-border exchanges of criminal information and intelligence, ensuring procedures for crossborder data exchanges are not stricter than those applying to exchanges at a national level. It regulates the conditions for exchanging information and intelligence among the EU Member States, including time limits and admissible justifications for refusing to share data. [2]

Looking back to the issue related to the exchange of information with operational importance at international level, as an important problematic aspect can be defined the way of transferring the information. Finding the appropriate channel for information exchange is of significant importance. Information with operational importance could be exchanged only via secured channels by using means as secure electronic mail, telephone, liaison officers etc. It should be mentioned that two of the largest international organization in the field of law enforcement, Europol and Interpol, also offer secure channels for exchange of information with operational importance - the SIENA platform of Europol and the system I-24/7 of Interpol.

\section{SIENA}

SIENA is an abbreviation of Secure Information Exchange Network Application - the platform, which enables the swift exchange of operational and strategic crime-related information among the authorized users. SIENA also ensures the secure exchange of sensitive and restricted information. [3]

The created and administrated by Interpol system I-24/7 is often defined as Secure Global Police Network. The I-24/7 global police communications system is developed with the idea to connect law enforcement officers in all member countries of Interpol. It enables authorized users to share sensitive and urgent police information with their counterparts. It also enables users to access INTERPOL's criminal databases. Authorized users can search and crosscheck data, with direct access to databases on suspected criminals or wanted persons, stolen and lost travel documents, stolen motor vehicles, fingerprints, DNA profiles, stolen administrative documents and stolen works of art. [4]

The biggest problem from practical point of view with regard to the international exchange of operational information between the law enforcement authorities in accordance to the framework of the Council Decision 2008/615/JHA (the so-called "Prüm Council Decision") and the Council Framework Decision 2006/960/JHA (the so-called "Swedish Initiative") is the absence of unified commonly accepted channel for information exchange. The practice shows that for the purpose of the exchange of information between the contracting parties of the Swedish initiative and/or of the Prüm Council Decision are equally used both channels for information exchange - the one offered by Interpol and the one offered by Europol. The aforementioned trend is a precondition for problems to occur related to the absence or insufficiency of coordination between the Europol National Unit and National Central Bureau of Interpol in one particular country as in some countries (as for example Bulgaria) they are separate organizational units in the same or different organizational structures without permanent contact between, which contact allows each of this two units to be fully aware of the work of the other one. Based on the last, it is absolutely possible a standardized form for information exchange according to the rules of the Swedish initiative to be submitted to Bulgaria simultaneously via the authorized channel of Europol and the authorized channel of Interpol and in this case, they will be dealt simultaneously and separately by the two units. In the best case, the aforementioned could be considerate as a 
waste of time and resources. In order the problem to be avoided an agreement should be met between the contracting countries applying in operational matters the Swedish Initiative and the Prüm Council Decision, one defined and commonly accepted channel for information exchange to be used.

Another practical problem is based on the fact that from one side, more or less the European Information Exchange Model (EIXM) is a tool for law enforcement cooperation among the EU member states, but from other side, not all member states of the EU apply the rules of the Swedish Initiative and the Prüm Council Decision on exchanging operational information in the field of law enforcement. The last is an obvious obstacle which should be overcome by encouraging all EU member states to become part of this common initiative for optimization of the information exchange.

The problem particularly exposed in relation to the Swedish initiative is the fact that often information has been requested which could be not directly accessible to the requested law enforcement authorities and which in the best case could be obtained as result of additional coordination with other institution or organization from the governmental or private sector. The consequence of the aforementioned is the delay of the delivery of the requested information with operational importance to the final "consumer" - the competent requesting law enforcement authority, in a way which does not allow the fixed in the Framework Decision 2006/960/JHA deadlines to be met. The practice also shows that cases, when the mechanism of the Swedish initiative is used a contracting country to be requested about information which is entirely not accessible for its national authorities, are not an exception. The last trend is violation of the principles of the Swedish initiative, because according to Article 5 "Requests for information and intelligence" of the Framework Decision 2006/960/JHA, "Information and intelligence may be requested for the purpose of detection, prevention or investigation of an offence where there are factual reasons to believe that relevant information and intelligence is available in another Member State. The request shall set out those factual reasons and explain the purpose for which the information and intelligence are sought and the connection between the purpose and the person who is the subject of the information and intelligence." [5]

In order the described in the paragraph problems to be avoided, it is necessary before submitting a standardized form for information exchange according to the rules of the Swedish initiative, the request for information to be thoroughly and precisely defined after consultations with the liaison officer of the requested country or other competent body with consultancy functions, if needed.

The last practical problem which will be covered briefly in the article is related to the direct access to information with operational importance stored in secured national databases managed by foreign contracting countries. Apparently, this is the most optimized and efficient way of accessing of information with operational importance, but is it currently possible in the EU dimension, considering the fact that it more or less affects the national sovereignty of each EU member state? The spontaneous answer of the question which will be given from each practitioner involved in the process of exchange of operational information in the field of law enforcement is that the European security now more than ever is a shared responsibility of all member states of the EU and if an effective tool in a favour of the security has been found, it should be developed without any prejudice. [6] Evidence about the aforementioned is the common platform EUCarIS envisaged by the Prüm Council Decision. The platform enables direct access to some information stored in the Vehicle Registers of the contracting countries - which information 
and way of accessing it are very useful from a practical point of view. The fact that the system currently works, despite the limited number of member states sharing information via the platform, is the beginning of new age of development of the law enforcement cooperation among Europe. Accessing information by avoiding the intermediary and the slow process of requesting and responding is no doubt faster, more efficient, more effective and allows to relocate the resources (mainly human power) engaged in the information exchange process. As a semi-automatic working platform for an exchange of operational information could be defined the approach adopted for the DNA-profiles exchange and Fingerprints Information Exchange both also envisaged by the Prüm Council Decision. The intermediary of the DNA-profiles exchange and Fingerprints Information Exchange is not entirely avoided but it is limited as the requesting country could find out by conducting a preliminary search in the database about the fact of eventual possession (or not) of one operational information related to DNA or Fingerprints profiles by another contracting country. The idea is, by searching information in the database, the so-called "hit" to generate a code which can be linked to the information only by the competent authority from the country, which has uploaded the information in the database.
The aforementioned is a precondition for delayed access of information with an operational importance which in some cases could be crucial for certain investigation or other specialized law enforcement activities. [7] The problem could be solved by finding an appropriate mechanism the systems for DNA-profiles exchange and Fingerprints Information Exchange to function in the same way as the platform EUCarIS envisaged by the Prüm Council Decision.

\section{Conclusion}

The briefly described above is only the top of the iceberg of the issues which might occur when implementing in practice the so-called European Information Exchange Model (EIXM). The frame drawn by the current article does not allow a deeper look at the problem defined in the title and suggesting comprehensive solutions with regard to the optimization of the exchange of operational information. Based on the text above a general conclusion can be made that the currently existed European Information Exchange Model (EIXM) is not the most proper and appropriate solution with regard to the exchange of information with operational importance in the field of law enforcement among the EU but it is acceptable starting point for further development in the right direction.

\section{References}

[1] COUNCIL DECISION 2008/615/JHA of 23 June 2008 on the stepping up of crossborder cooperation, particularly in combating terrorism and cross-border crime http://eur-lex.europa.eu/legal-content/EN/ALL/?uri=CELEX:32008D0615

[2] https://ec.europa.eu/home-affairs/what-we-do/policies/police-cooperation/informationexchange/eixm en

[3] https://www.europol.europa.eu/activities-services/services-support/informationexchange/secure-information-exchange-network-application-siena

[4] https://www.interpol.int/INTERPOL-expertise/Data-exchange/I-24-7

[5] COUNCIL FRAMEWORK DECISION 2006/960/JHA of 18 December 2006 on simplifying the exchange of information and intelligence between law enforcement authorities of the Member States of the European Union - http://eurlex.europa.eu/LexUriServ/LexUriServ.do?uri=OJ:L:2006:386:0089:0100:EN:PDF 
[6] Marin, N., Disproportionate Migration Pressure as a Challenge for the National Security of the Republic of Bulgaria, Economic, Social and Administrative Approaches to the Knowledge-Based Organization, "Nicolae Bălcescu" Land Forces Academy Publishing House, SIBIU, Romania De Gguyter Open, Vol. XXII, Conference Proceedings No 2, 2016, pp. 132-137. ISSN 18-43-682X; ISBN 978-973-153-246-2.

[7] Belova G., Marin N. \& Georgieva G. CONFLICT PREVENTION ACTIVITIES In: Proceedings of the International Scientific Conference "Contemporary Concepts of Crisis Management” December 2016 Ohrid, Republic of Macedonia, Skopje April 2017, organized by CRISIS MANAGEMENT CENTER, REPUBLIC OF MACEDONIA, GOCE DELCEV UNIVERSITY - STIP, KOLEGJI BIZNESI UNIVERSITY - PRISTINA, REPUBLIC OF KOSOVO, JOHNS HOPKINS UNIVERSITY, USA; ISBN 978-608-65931-0-0, pp.33-41. 